\title{
Chemical composition, fatty acid profile and colour of broiler meat as affected by organic and conventional rearing systems
}

\author{
K. Küçükyılmaz ${ }^{1}$, M. Bozkurt ${ }^{1 \#}$, A.U. Çatlı ${ }^{1}$, E.N. Herken ${ }^{2}$, M. Çınar ${ }^{1}$ \& E. Bintaş ${ }^{1}$ \\ ${ }^{1}$ Erbeyli Poultry Research Institute - Aydın/Turkey \\ ${ }^{2}$ Department of Food Engineering, Faculty of Engineering, Pamukkale University, Denizli,Turkey
}

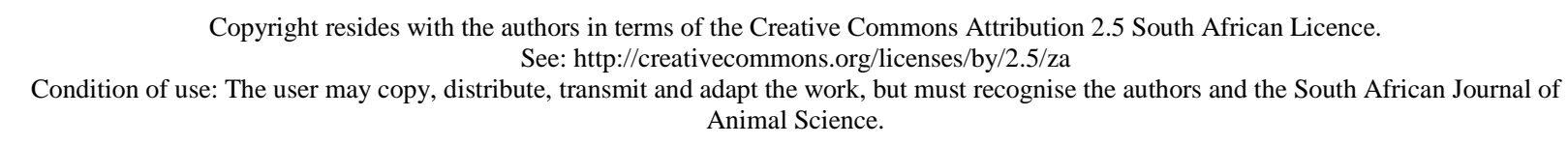

\begin{abstract}
The major quality characteristics of breast and thigh meat, including chemical composition, fatty acid composition, cholesterol content and colour of slow-growing broilers (Hubbard Red-JA), reared under either organic or conventional rearing systems, and fast-growing broilers (Ross-308) grown under the conventional procedure, were investigated in this comparative study. Slaughter age was 81 days and 42 days for slow- and fast-growing birds, respectively. A lower protein, but higher fat content was measured in the thigh meat of slow-growing broilers reared both in the organic and conventional systems, compared with conventionally reared fast growers. In both systems the breast meat of fast-growing birds had a higher moisture content than those of the slow-growing birds. The organic system promoted ash retention in breast meat compared with conventional rearing procedures. The fatty acid profile of thigh and breast meat showed different responses to broiler rearing systems. Both thigh and breast meat of conventionally reared slow-growing birds contained higher cholestorel levels. Breast and thigh meat yielded from conventionally reared fast-growing birds had a markedly higher red appearance, but a lower yellow colour, than those of slow growers. The organic system increased the yellowness of the meat. In conclusion, the organic rearing procedure provided no added benefit to chicken meat quality than current conventional applications, except in yellowness. Meat produced from birds in the organic system did not meet consumer expectations of presenting a lower $n-3$ but a higher n- $6 / n-$ 3 ratio in thigh meat.
\end{abstract}

Keywords: Fast-growing broilers, slow-growing broilers, organic production, meat quality

\#Corresponding author: mehmetbozkurt9@hotmail.com

\section{Introduction}

Poultry meat production in the world exceeded 92 million tons in 2009 and constituted one third of global meat production (Evans, 2008). Commercial broiler hybrids reach market weight within 40 days, with excellent feed conversion efficiencies and high yields of edible cuts. However, the rapid growth of fastgrowing modern lines leads to welfare concerns, especially because of metabolic disorders (Owens et al., 2006). It is evident that the genotype of the bird influences the meat quality of broiler chickens considerably. It has been reported that selection for fast growth and high yield is likely to affect the sensory and functional properties of chicken meat (Dransfield \& Sosnicki, 1999; Le Bihan-Duval et al., 1999). Therefore, differences in meat quality may derive from the notable differences in growth rate between fast- and slowgrowing broiler strains (Fanatico et al., 2005). The rearing of slow-growing genotypes in organic production systems, even raising them indoors, holds potential for non-conventional broiler producers and should be evaluated.

In recent times, consumers have been increasingly interested in products that they perceive as naturally produced or environmentally friendly. Consumers want chickens that provide a high level of nutrition with no contaminants, good flavour and rearing techniques that offer good welfare and health for the bird (Sundrum, 2001; Owens et al., 2006). Indeed, there is a common belief that organic chickens are safer and more nutritious than conventional ones, and therefore an increasing number of consumers are 
willing to pay a premium for free-range or certified organic chicken meat (Castellini et al., 2008; Crandall et al., 2009). As far as the qualitative characteristics of chicken meat are concerned, there is a controversy as to whether the alternative systems result in better quality and taste than conventional rearing systems. Previous studies suggested that factors such as strain of the bird and type of rearing system have a great impact on meat quality features (Castellini et al., 2002a; b; 2008; Quentin et al., 2003; Fanatico et al., 2005; Grashorn 2005; Husak et al., 2008; Crandall et al., 2009).

Broilers reared in alternative production systems are encouraged to forage and benefit from the vegetation, thereby increasing their choice of environment and food source (Castellini et al., 2002a; Grashorn, 2005; Husak et al., 2008; Martino et al., 2008). Hence, one of the principal expectations from outdoor access and feeding on organic diets is improvement in the functional quality of chicken meat.

An increasing number of studies has compared meat quality from organic, free-range and conventional broiler production systems (Castellini et al., 2002; Grashorn, 2005; Owens et al., 2006; Husak et al., 2008; Ponte et al., 2008). However, relatively few studies have reported on the meat quality features of slowgrowing broiler genotypes grown without outdoor access (Fanatico et al., 2005).

The aim of this study was to compare certain quality features of the meat obtained from conventionally reared fast-growing broilers and a slow-growing genotype reared under the conventional system or under a certified organic production system.

\section{Materials and Methods}

This study was conducted at the experimental units of the Erbeyli Poultry Research Institute. The Ministry of Agriculture, General Directorate of Research Institutional Animal Care and Use Committee, approved the techniques and procedures involved in animal care and handling. A total of 400 commercial slow-growing Hubbard Red-JA and 200 commercial fast-growing Ross-308 one-day-old broiler chicks of mixed sex were used in this study. Birds were randomly assigned to one of three rearing conditions. While the slow-growing broilers were reared under either organic (SGO) or conventional conditions (SGC), the fast-growing birds were reared only under the conventional system (FGC). Each rearing system was accepted as an experimental group and sub-divided into four replicates of 50 broiler chicks. The fast-growing modern broiler strain was not used for organic chicken production for practical reasons. This is why this study was not arranged according to a factorial design. Three rearing systems were applied and are described below:

1. FGC: A total of 200 1-day-old fast-growing broiler chickens (Ross 308) were placed in an opensided, naturally lit and ventilated broiler house. Standard management practices were applied as recommended by the breeder (Ross 308, Commercial Management Guide, 2006). The birds were subdivided into four replicates of 50 birds per replicate and kept in four deep-litter pens $(1.4 \mathrm{~m} \times 3.0 \mathrm{~m})$ on wood shavings. The lighting schedule was $23 \mathrm{~h}$ light, $1 \mathrm{~h}$ dark. Each pen was equipped with two hanging feeders, one bell drinker, and two infrared lamps. Bird density was 12 chicks per square metre.

2. SGC: The same number of day-old broiler chickens (200) of slow-growing genotype (Hubbard Red JA) was reared under the same management procedures of the FGC treatment, except for diet type and lighting schedule. Artificial lighting was not provided for the conventionally reared slow-growing birds.

3. SGO: In the organic rearing system, 200 slow-growing broiler chickens (Hubbard Red JA) were randomly divided into four replicates, which were located $50 \mathrm{~m}$ from the conventional house. Each replicate of 50 birds had access to a $10 \mathrm{~m}^{2}$ shelter with deep litter (6 cm wood shavings) and a $200 \mathrm{~m}^{2}$ outdoor area covered with natural pasture. The shelters located in the centre of the outdoor pasture were made of insulated aluminium panels on an iron frame, and windows were placed on one side of the house to allow daylight into the house. The indoor space ( 5 birds $/ \mathrm{m}^{2}$ ) was furnished with two circular hanging feeders, a bell drinker, and a tree-tier perch (30 cm/bird). Two drinkers and two perches were available in the outdoor area too. The natural pasture included a lucerne-trifolium mixture, which was available for consumption throughout the experimental period (22 to 81 days). The pop-holes in the shelter were open during daylight, giving free access to the outdoor area throughout the experiment. Artificial lighting was not available.

The diets in mash form and water were provided ad libitum. Experimental feed mixtures used in the organic and conventional systems were based on maize, wheat, soybean meal and sunflower meal. Similar ingredients were used when formulating diets in order to avoid differences in ingredient composition. As established by EC Regulation 1804/99, at least $80 \%$ of dry matter content of the organic feed mixture was provided from organically grown ingredients. Soybean meal (GMO free) was the only conventional feed ingredient supplemented to the organic feed mixture at an inclusion level of $20 \%$. Lucerne meal, which was 
derived from the whole plant grown under organic farming conditions, was added to the organic feed as a roughage source.

Chick starter and grower diets were given to the fast-growing broilers between 0 and 21 days and 22 and 42 days, respectively. Unlike the usual schedule, the slow-growing birds were fed on a starter diet between 0 and 28 days and a grower diet between 29 and 81 days (Table 1).

Table 1 Composition and chemical analysis of the experimental diets

\begin{tabular}{|c|c|c|c|c|c|c|}
\hline \multirow[b]{2}{*}{ Ingredient } & \multicolumn{3}{|c|}{ Starter diets (g/kg) } & \multicolumn{3}{|c|}{ Grower diets (g/kg) } \\
\hline & $\begin{array}{l}\text { Fast- } \\
\text { growing } \\
\text { conven. }\end{array}$ & $\begin{array}{l}\text { Slow- } \\
\text { growing } \\
\text { conven. }\end{array}$ & $\begin{array}{l}\text { Slow- } \\
\text { growing } \\
\text { organic }\end{array}$ & $\begin{array}{c}\text { Fast- } \\
\text { growing } \\
\text { conven. }\end{array}$ & $\begin{array}{l}\text { Slow- } \\
\text { growing } \\
\text { conven. }\end{array}$ & $\begin{array}{l}\text { Slow- } \\
\text { growing } \\
\text { organic }\end{array}$ \\
\hline Maize & 314 & 414 & 397 & 352 & 398 & 389 \\
\hline Wheat & 220 & 190 & 199 & 220 & 200 & 200 \\
\hline Soybean meal (48 \%) & 222 & 211 & 220 & 177 & 160 & 180 \\
\hline Fullfat soy bean & 60 & - & - & 60 & - & - \\
\hline Lucerne meal & - & 5.0 & 5.0 & - & 50 & 50 \\
\hline Sunflower meal & 110 & 107 & 120 & 110 & 120 & 120 \\
\hline Sunflower oil & 36 & 36 & 22 & 46 & 38 & $2 /$ \\
\hline Ground limestone & 12 & 15 & 16 & 12 & 14 & 14 \\
\hline Dicalcium phosphate & 14 & 16 & 16 & 13 & 14 & 14 \\
\hline Salt & 2.5 & 2.5 & 2.5 & 2.5 & 2.5 & 2.5 \\
\hline Vitamin premix* & 2.5 & 2.5 & 2.5 & 2.5 & 2.5 & 2.5 \\
\hline Mineral premix** & 1.0 & - & - & 1.0 & - & - \\
\hline Coccidiostat & 0.5 & - & - & 0.5 & - & - \\
\hline DL-methionine & 1.9 & - & - & 1.4 & - & - \\
\hline L-lysine & 1.84 & - & - & 1.15 & - & - \\
\hline Essential oil mixture & 1.0 & 1.0 & 1.0 & 1.0 & 1.0 & 1.0 \\
\hline \multicolumn{7}{|c|}{ Chemical composition (g/kg DM) } \\
\hline Dry matter & 894 & 901 & 900 & 894 & 902 & 903 \\
\hline Crude protein & 211 & 194 & 195 & 190 & 182 & 182 \\
\hline $\mathrm{ME}(\mathrm{KJ})$ & 126 & 128 & 128 & 130 & 127 & 127 \\
\hline Crude fat & 66 & 68 & 69 & 77 & 70 & 71 \\
\hline Crude cellulose & 49 & 57 & 58 & 48 & 71 & 72 \\
\hline Crude Ash & 65 & 64 & 64 & 63 & 62 & 61 \\
\hline Calcium & 9.0 & 10.5 & 10.8 & 8.5 & 10.1 & 10.6 \\
\hline Total phosphorus & 6.6 & 6.8 & 6.5 & 6.2 & 6.3 & 6.2 \\
\hline Lysine $^{2}$ & 12.5 & 9.0 & 9.2 & 10.5 & 8.3 & 8.2 \\
\hline Methionine+cysteine ${ }^{2}$ & 8.8 & 6.3 & 6.6 & 7.8 & 6.3 & 6.2 \\
\hline Methionine $^{2}$ & 5.2 & 3.3 & 3.3 & 4.5 & 3.2 & 3.1 \\
\hline
\end{tabular}

${ }^{\mathrm{T}}$ Soybean meal was the only conventional feed ingredient included in the organic feed mixture.

*2.5 kg vitamin premix consists of $12.000 .000 \mathrm{IU}$ vitamin $\mathrm{A} ; 1.500 .000 \mathrm{IU}$ vitamin $\mathrm{D}_{3} ; 30.000 \mathrm{mg}$ vitamin E; $5.000 \mathrm{mg}$ vitamin $K_{3} ; 3.000 \mathrm{mg}$ vitamin $B_{1} ; 6.000 \mathrm{mg}$ vitamin $B_{2} ; 5.000 \mathrm{mg}$ vitamin $B_{6}$ : $30 \mathrm{mg}$ vitamin $B_{12}: 40.000$ mg nicotine amid; $10.000 \mathrm{mg}$ calcium-D-pentothenate; $750 \mathrm{mg}$ folic acid; $75 \mathrm{mg}$ D-biotine; $375.000 \mathrm{mg}$ choline chloride.

${ }^{* *} 1 \mathrm{~kg}$ mineral premix consists of 80.000 mg Mn; 80.000 mg Fe; 60.000 mg Zn; 8.000 mg Cu; 500 mg I; 200 mg Co; $150 \mathrm{mg}$ Se; $10.000 \mathrm{mg}$ antioxidant.

${ }^{2}$ Calculated composition. 
The chemical composition of the ingredients and feed mixtures was analysed according to AOAC (1995) methods, and the metabolizable energy was calculated based on the standard procedures (Anonymous, 1991). The ingredient composition of the feed mixtures is presented in Table 1.

The slow-growing birds were slaughtered at 81 days of age while the fast-growing ones were slaughtered at 42 days. To determine the chemical composition of the meat, 12 male broilers of similar body weight to the group average were slaughtered by severing the jugular vein in the experimental processing unit of the institute, $8 \mathrm{~h}$ after feed withdrawal. Chicks were electrically stunned ( $40 \mathrm{~V}$; $50 \mathrm{~Hz}$ ) before killing. After killing, the carcasses were immerged into hot water $\left(60^{\circ} \mathrm{C}\right.$ for $\left.62 \mathrm{~s}\right)$, then plucked and manually eviscerated. The same slaughtering procedure was applied for meat colour determination which is described below. After evisceration, breast and thigh meat parts were cut off and minced separately.

The ash, moisture, protein, fat, fatty acid composition and cholesterol contents were analysed on the meat samples after 24 hours of storage at $4{ }^{\circ} \mathrm{C}$. Analyses for moisture, crude protein, crude fat and crude ash were performed according to the methods specified by AOAC (1995). All chemical analyses were carried out in triplicate.

The lipid and fatty acids in the meat were extracted as per Folch et al. (1957) using chloroform : methanol (2:1). Fatty acid methyl esters were prepared from the total lipid extract, using methanolic $\mathrm{HCl}$ as the derivatizing agent (Husak et al., 2008). Analyses of fatty acid methyl esters were performed with an Agilent 6890 gas chromatograph (Agilent Technologies Inc., Palo Alto, CA) equipped with an auto sampler, a flame ionization detector and a fused silica capillary column of $30 \mathrm{~m} \times 0.25 \mathrm{~mm} \times 0.2 \mu \mathrm{m}$ film thickness. Chromatographic conditions were as follows: The temperature in the detector was $250{ }^{\circ} \mathrm{C}$, in the injector, $225^{\circ} \mathrm{C}$ and in the column, $180^{\circ} \mathrm{C}$; the carrier gas was helium with a flow rate $0.7 \mathrm{~cm}^{3} / \mathrm{min}$; the length of the capillary column was $30 \mathrm{~m}$ with an internal diameter $0.32 \mathrm{~mm}$. Peak areas and fatty acid percentages were calculated using Agilent ChemStation software. Fatty acid methyl esters were identified by comparison with retention times and are reported as percentage of fatty acid methyl esters. An internal standard C19:0 was used for fatty acid quantification. Saturated fatty acid content, monounsaturated fatty acid content, and polyunsaturated fatty acid content are described as SFA, MUFA, and PUFA, respectively, hereafter.

Total cholesterol in meat samples was extracted using the direct saponification procedure of Adams et al. (1986). The cholesterol concentration of derivatized extracts in dimethylformamide was quantified by gas chromatography analysis on an Agilent Technologies 6890 gas chromatograph equipped with a flame ionisation detector and glass column.

For measuring meat colour, 72 broilers representing 24 broilers of each group were slaughtered. The breast and thigh meats were separated with their skin on and the colour values of these samples were determined according to the CIELAB method, using a Minolta CR-400 (USA) colorimeter apparatus. Lightness, redness, and yellowness values, $\mathrm{L}^{*}, \mathrm{a}^{*}$, and $\mathrm{b}^{*}$, respectively, are presented according to this method. The spectrocolorimeter was programmed to calculate the average of three separate colour readings and was calibrated against a standard calibration ceramic tile (Reference No. 16033018 . $\mathrm{L}^{*}=98.46$, $\mathrm{a}^{*}=$ $\left.0.16, b^{*}=2.68\right)$. Data were analysed as a one-way ANOVA using the general linear models procedures of the SAS (1995). Arc-sin transformation was applied before the percentage values were analysed. The significant differences among means of treatments were determined by Duncan's multiple range test with 5\% probability.

\section{Results and Discussion}

Chemical analysis, fatty acid composition and cholesterol content, and L*, a*, b* colour values of the breast and thigh meat of the broilers reared under organic and conventional systems are presented in Tables 2,3 , and 4 , respectively.

The rearing system influenced some of the traits concerning the chemical composition of the breast and thigh meat $(P<0.05)$. The meat to fat ratio of thigh meat was found to be higher in the SGO and SGC treatments compared with the FGC treatment. While the protein content of thigh meat was higher in the FGC birds, the protein content of breast meat did not differ significantly between the different rearing systems ( $P$ $>0.05$ ). Rearing broilers in the SGO instead of the SGC system caused a significant difference only in the breast ash content, and not in other characteristics.

It is well known that moisture content is one of the main determinants of chicken meat quality (Castellini et al., 2002b). Different broiler rearing systems showed no effect on the moisture content of thigh meat, but influenced that in breast meat $(P<0.01)$. The moisture content in the breast meat of the SGO birds 
was similar to that in the SGC birds, while both were lower to that in FGC birds. This indicates that the organic rearing system was not able to provide benefits in meat moisture content compared with conventional systems. Indeed, inconsistent results have been reported on the effects of rearing system on meat moisture content. While Martino et al. (2008) reported that there was no difference between the meat moisture content of organic and conventional broilers, findings in several other studies (Grashorn \& Serini, 2006; Husak et al., 2008) agreed with the present results, indicating a lower moisture content in the breast meat of organically reared birds compared with birds reared conventionally.

The organic system increased ash retention in breast meat compared with conventional rearing systems. This higher ash content could be due to the selected intake and ingestion of small stones from the soil that is rich in minerals. Some earlier studies contradicted these findings, indicating that meat ash content was not affected by genotype whether birds were given free access to an outdoor area or not (Castellini et al., 2002b; 2006; Fanatico et al., 2007). However, Castellini et al. (2002a) reported an increase in meat ash content of organically reared birds, in agreement with the present results.

Difference in the protein content of thigh meat indicted genotypic differences in this study. It is obvious that fast-growing broilers had higher meat protein levels compared with slow-growing birds both for those kept indoor and those given outdoor access under the organic system. Similarly, Castellini et al. (2002b) reported that fast-growing broilers had higher meat protein levels than slow growers. However, the contrary was stated by Wattanachant et al. (2004) and Castellini et al. (2006), showing a similarity among genotypes in terms of thigh protein level. The results of this study confirm findings of previous studies (Castellini et al., 2002a; Martino et al., 2008) that reported that the protein content of poultry breast meat did not differ between organic and conventional production systems. In contrast, others reported higher protein contents in meats yielded from organically reared birds (Grashorn \& Serini 2006; Husak et al., 2008) or broilers given free access to an outdoor area (Fanatico et al., 2007). Such discrepancies between studies regarding the chemical composition of the chicken meat might have derived from differences in management procedures, such as slaughter age, nutrient density and bird genotype.

Table 2 Chemical composition of breast and thigh meat from broilers reared under organic or conventional systems

\begin{tabular}{lccccc}
\hline & $\begin{array}{c}\text { Conventional } \\
\text { fast-growing }\end{array}$ & $\begin{array}{c}\text { Conventional } \\
\text { slow-growing }\end{array}$ & $\begin{array}{c}\text { Organic slow- } \\
\text { growing }\end{array}$ & Mean Std. Error & $P$ value \\
\hline Thigh meat (\%) & & & & & \\
Moisture & 73.4 & 73.9 & 73.8 & 0.34 & 0.5030 \\
Ash & 0.94 & 0.91 & 0.89 & 0.02 & 0.1070 \\
Fat & $6.54^{\mathrm{b}}$ & $8.29^{\mathrm{a}}$ & $8.11^{\mathrm{a}}$ & 0.30 & 0.0138 \\
Protein & $18.6^{\mathrm{a}}$ & $17.4^{\mathrm{b}}$ & $17.3^{\mathrm{b}}$ & 0.25 & 0.0393 \\
Breast meat (\%) & & & & & \\
Moisture & $74.1^{\mathrm{a}}$ & $72.7^{\mathrm{b}}$ & $72.9^{\mathrm{b}}$ & 0.19 & 0.0017 \\
Ash & $1.15^{\mathrm{ab}}$ & $1.10^{\mathrm{b}}$ & $1.20^{\mathrm{a}}$ & 0.02 & 0.0350 \\
Fat & 2.41 & 2.81 & 2.66 & 0.09 & 0.6075 \\
Protein & 22.4 & 22.7 & 22.6 & 0.10 & 0.4529
\end{tabular}

${ }^{\mathrm{a}, \mathrm{b}}$ Means within rows the different superscript are significantly different $(P<0.05)$.

Free access to outdoor areas in the organic system did not modify the meat fat content of slowgrowing broilers compared with those kept indoors. These findings are in agreement with related works (Grashorn \& Serini, 2006; Martino et al., 2008) that reported that broilers in organic systems had a higher meat fat content than conventionally reared birds. The assumption is that fast-growing birds are less active, but spend more time sitting, especially towards the end of the fattening period, owing to their higher body weight (Wattanachant et al., 2004; Castellini et al., 2006). Since the slow-growing broilers in the organic system were more active than those kept indoors, the similarity in thigh meat fat content between SGO and 
SGC birds indicates that bird genotype was more prominent than rearing system in terms of fat deposition in thigh meat tissues.

The fatty acid profiles of thigh and breast meat were affected significantly by rearing system. However, the relatively impact was apparently more in thigh meat than in breast meat in the alternative rearing systems. The MUFA contents of breast and thigh meat showed different patterns. PUFA content differed significantly in both meat cuts in response to the differences in the rearing systems. Birds in the FGC treatment had a higher MUFA content, but a lower PUFA content in their breast meat when compared with birds reared in the SGO system $(P<0.05)$. Values obtained from the SGC group were intermediate. Contrary to the pattern in breast meat, the PUFA content of thigh meat in the FGC birds was found to be higher when compared with the values determined in SGO and SGC birds. An tendency was also seen in thigh meat MUFA content, which approached statistical significance $(P=0.0952)$.

Omega-3 fatty acid concentration of thigh meat differed $(P<0.01)$ between the rearing systems; FGC being the highest, SGO the lowest, and the SGC intermediate. The breast meat of birds in the SGO treatment had higher omega-6 values than that of FGC birds, whereas the opposite was found in the thigh meat. Significant $(P<0.05)$ differences were found in the $n-6 / n-3$ ratio in thigh meat between the rearing systems, whereas insignificant $(P>0.05)$ differences were determined in breast meat.

Table 3 Fatty acid profile (\% total fatty acids) and cholesterol concentration (mg/100 g meat) of thigh and breast meat from broilers reared under organic or conventional systems

\begin{tabular}{|c|c|c|c|c|c|}
\hline Fatty acids (\%)* & $\begin{array}{l}\text { Conventional fast- } \\
\text { growing } \\
\end{array}$ & $\begin{array}{l}\text { Conventional } \\
\text { slow-growing } \\
\end{array}$ & $\begin{array}{l}\begin{array}{l}\text { Organic slow- } \\
\text { growing }\end{array} \\
\end{array}$ & $\begin{array}{l}\text { Mean Std. } \\
\text { Error } \\
\end{array}$ & $P$ value \\
\hline \multicolumn{6}{|l|}{ Thigh meat } \\
\hline SFA & 22.9 & 22.4 & 24.2 & 0.62 & 0.1752 \\
\hline MUFA & 39.2 & 45.7 & 44.2 & 1.80 & 0.0952 \\
\hline PUFA & $37.7^{\mathrm{a}}$ & $31.7^{\mathrm{b}}$ & $31.4^{\mathrm{b}}$ & 1.42 & 0.0353 \\
\hline$\Sigma \mathrm{n}-6$ & $34.5^{\mathrm{a}}$ & $30.8^{b}$ & $30.5^{b}$ & 0.91 & 0.0376 \\
\hline$\Sigma \mathrm{n}-3$ & $1.14^{\mathrm{a}}$ & $0.78^{b}$ & $0.60^{\mathrm{c}}$ & 0.04 & 0.0004 \\
\hline$n-6 / n-3$ & $30.8^{c}$ & $39.2^{\mathrm{b}}$ & $50.7^{\mathrm{a}}$ & 2.26 & 0.0024 \\
\hline PUFA/SFA & $1.64^{\mathrm{a}}$ & $1.41^{\mathrm{b}}$ & $1.29^{\mathrm{b}}$ & 0.06 & 0.0051 \\
\hline Cholesterol & $134.7^{\mathrm{b}}$ & $174.0^{\mathrm{a}}$ & $158.4^{\mathrm{ab}}$ & 10.99 & 0.0204 \\
\hline \multicolumn{6}{|l|}{ Breast meat } \\
\hline SFA & 24.0 & 24.0 & 24.3 & 0.53 & 0.9078 \\
\hline MUFA & $44.4^{\mathrm{a}}$ & $43.6^{\mathrm{ab}}$ & $42.5^{b}$ & 0.42 & 0.0469 \\
\hline PUFA & $31.4^{\mathrm{b}}$ & $32.2^{\mathrm{ab}}$ & $33.0^{\mathrm{a}}$ & 0.38 & 0.0498 \\
\hline$\Sigma \mathrm{n}-6$ & $30.2^{\mathrm{b}}$ & $31.3^{\mathrm{ab}}$ & $32.1^{\mathrm{a}}$ & 0.35 & 0.0272 \\
\hline$\Sigma \mathrm{n}-3$ & 0.99 & 0.61 & 0.68 & 0.13 & 0.2044 \\
\hline$n-6 / n-3$ & 36.8 & 50.9 & 46.7 & 5.19 & 0.2226 \\
\hline PUFA/SFA & 1.31 & 1.34 & 1.36 & 0.05 & 0.7386 \\
\hline Cholesterol & $36.8^{b}$ & $62.7^{\mathrm{a}}$ & $53.7^{\mathrm{ab}}$ & 8.58 & 0.0267 \\
\hline
\end{tabular}

${ }^{a, b, c}$ Means within rows the different superscript are significantly different $(P<0.05)$.

*SFA: saturated fatty acid; MUFA: mono unsaturated fatty acid; PUFA: polyunsaturated fatty acid.

The fatty acid composition in the meat shows varying responses in the different rearing systems. However, most studies indicated higher PUFA, n-3 and n-6 concentrations when birds were grown under organic and free range systems (Jahan et al., 2004; Grashorn \& Serini, 2006; Husak et al., 2008; Martino et al., 2008). The fatty acid composition of the chicken meat was also significantly influenced by the rearing system in the present study. One of the reasons for these discrepancies among investigations was attributed to the green grass consumption of broilers in organic systems. Martino et al. (2008) pointed out a correlation between the PUFA content of feed and meat. However, Ponte et al. (2008) reported that the fatty acid composition of meat from free-range broilers was modified only slightly by grass consumption. Although pasture intake was available for the birds in the organic system in this study between the ages of 21 and 81 days, the thigh meat of the organically reared birds was markedly lower in omega-3 content when compared 
with birds kept indoors. The report by Jahan et al. (2004), that demonstrated that organic breast meat had a significantly lower contents of n-3 fatty acids, but a higher content of total PUFA, n-6 and n-6/n-3 ratios, is in full agreement with the present findings. Also, a recent study showed that free-range meat contained lower quantities of most n-3 fatty acids (C18:3, C18:4, EPA) and had a consistently higher n-6/n-3 ratio than that from intensively reared birds (Givens et al., 2011). It has been suggested that broiler chicks in an organic system are usually exposed to more and different environmental factors compared with the conventional indoor systems; hence, they might have utilized omega-3 as an essential nutrient to support their immune system against external stimulations, rather than deposit it in the meat. The indication by Cook et al. (1993) that omega-3 stimulates the body's physiological process during stress appears to confirm our corresponding approach.

The cholesterol content of thigh and breast meat in the SGC treatment were notably higher $(P<0.05)$ than that of the FGC treatment, while the value in the SGO birds stood at the intermediate level. Both cholesterol concentrations breast and thigh meat of the FGC birds were lower than in the SGC birds. Rearing slow-growing birds in an organic system resulted in only a slight decrease in meat cholesterol concentration in this study when compared with their counterparts kept indoors under the conventional procedure. The observations of Ponte et al. (2008) showed that grass consumption did not induce any change in meat cholesterol concentration.

Colour $\mathrm{a}^{*}$ values in thigh meat of birds in the FGC treatment was higher than that of SGC and SGO treatments, while the opposite was observed in the $b^{*}$ values $(P<0.01)$. Colour $\mathrm{a}^{*}$ values in breast meat followed the same trend as that of thigh meat. Breast meat $\mathrm{L}^{*}$ values in SGC and SGO birds were higher than the values in the FGC birds. The $b^{*}$ values of breast and thigh meat, representing the yellowness, was higher $(P<0.01)$ in the SGC and SGO treatments in comparison with the FGC treatment. The $\mathrm{b}^{*}$ values of breast meat in the SGO treatment were much higher than those obtained in the SGC treatment.

Table $4 \mathrm{~L}^{*}$, a* and $\mathrm{b}^{*}$ colour values of meat from broilers reared under organic or conventional systems

\begin{tabular}{cccccc}
\hline & $\begin{array}{c}\text { Conventional } \\
\text { fast-growing }\end{array}$ & $\begin{array}{c}\text { Conventional } \\
\text { slow-growing }\end{array}$ & $\begin{array}{c}\text { Organic slow- } \\
\text { growing }\end{array}$ & Mean Std. Error & $P$ value \\
\hline Thigh meat & & & & & \\
$\mathrm{L}^{*}$ & 64.1 & 64.5 & 64.9 & 0.96 & 0.7100 \\
$\mathrm{a}^{*}$ & $2.91^{\mathrm{a}}$ & $1.25^{\mathrm{b}}$ & $1.42^{\mathrm{b}}$ & 0.29 & 0.0001 \\
$\mathrm{~b}^{*}$ & $3.91^{\mathrm{b}}$ & $6.53^{\mathrm{a}}$ & $7.82^{\mathrm{a}}$ & 1.02 & 0.0012 \\
Breast meat & & & & & \\
$\mathrm{L}^{*}$ & $60.6^{\mathrm{b}}$ & $63.6^{\mathrm{a}}$ & $63.8^{\mathrm{a}}$ & 0.83 & 0.0004 \\
$\mathrm{a}^{*}$ & $1.99^{\mathrm{a}}$ & $0.41^{\mathrm{b}}$ & $0.86^{\mathrm{b}}$ & 0.32 & 0.0001 \\
$\mathrm{~b}^{*}$ & $3.84^{\mathrm{c}}$ & $7.94^{\mathrm{b}}$ & $9.71^{\mathrm{a}}$ & 0.89 & 0.0001 \\
\hline
\end{tabular}

${ }^{\mathrm{a}, \mathrm{b}, \mathrm{c}}$ Values within rows the different superscript are significantly different $(P<0.05)$

Thigh and breast meat of slow-growing birds kept both indoors and grown under the organic production system appeared to be brighter and yellower when compared with fast-growing birds. This concurs with other reports (Castellini et al., 2002a; Nielsen et al., 2003; Jahan et al., 2004; Fanatico et al., 2005; 2007; Grashorn \& Serini 2006; Owens et al., 2006). Most of these researchers agreed on the higher b* values observed in meat from slow-growing and organic broilers, which might have been derived from the consumption of green grass. We also associate the increased yellowness in meat to pasture intake in the present study. It was demonstrated that herbal intake, in addition to consumption of feed mixture, caused a rise in the yellowness of meat due to the higher carotenoid pigment content (Akiba et al., 2001; Toyomizu et al., 2001). Skin colour depends on the melanine pigment production ability of the dermis and epidermis and also on absorption and storage of carotenoid pigments in the epidermis (Fletcher, 1999). However, several investigations indicated lower meat $\mathrm{L}^{*}$ values in slow-growing birds although they were allowed outdoor access (Castellini et al., 2002b; Fanatico et al., 2007). There was no difference between $\mathrm{L}^{*}$ values of organic 
and conventional meats (Grashorn \& Serini, 2006). The results obtained clearly indicated that rearing fastgrowing birds in a conventional system (FGC) induced a more red appearance in chicken meat as compared to the other systems (SGC and SGO). While these findings agree with the results of Fanatico et al. (2005; 2007), contradictory results were reported in other studies (Castellini et al., 2002a; Nielsen et al., 2003).

\section{Conclusions}

In conclusion, different types of rearing system resulted in significant changes in the chemical composition, fatty acid composition, cholesterol content and colour of breast and thigh meats. Rearing slowgrowing broilers in an organic system provided no benefit except in skin colour b* values. Nevertheless, it resulted in a reduction in the omega-3 content of thigh meat. Overall results indicated that alternative rearing systems in broiler production do not ensure additional health benefits for consumers regarding chicken meat quality. More research is needed to clarify the effects of pasture intake, composition of pasture, nutrient density of compound feed, and bird genotype on the meat quality of organically reared broilers.

\section{Acknowledgement}

This project was supported by Turkish Ministry of Agriculture and Rural Affairs, Project No: TAGEM/HAYSÜD/06/12/01/01.

\section{References}

Adams, M.L., Sullivan, D.M., Smith, R.L. \& Richter, E.F., 1986. Evaluation of direct saponification method for determination of cholesterol in meats. J. Assoc. Offic. Anal. Chem. 69, 844-846.

Akiba, Y., Sato, K., Takahashi, K., Toyomizu, M., Matsushita, K. \& Komiyaha, H., 2001. Meat color of broiler chickens as affected by age and feeding of yeast phaffa rhodozyma containing high concentrations of astaxanthin. Anim. Sci. J. 72, 147-153.

Anonymous, 1991. Animal feeds determination of metabolisable energy (chemical method). Turkish Standards Institute (TSE), Publ. No. 9610, pp. 1-3.

AOAC, 1995. Official methods of analysis (16th ed.). Association of Official Analytical Chemists, Inc., Washington D.C., USA.

Castellini, C., Mugnai, C. \& Dal Bosco, A., 2002a. Effect of organic production system on broiler carcass and meat quality. Meat Sci. 60, 219-225.

Castellini. C., Mugnai, C. \& Dal Bosco, A.. 2002b. Meat quality of three chicken genotypes reared according to the organic system. Ital. J. Food. Sci. 4, 401-412.

Castellini, C., Dal Bosco, A., Mugnai, C. \& Pedrazzoli, M., 2006. Comparison of two genotypes organically reared: oxidative stability and other qualitative traits of the meat. Ital. J. Anim. Sci. 5, 29-42.

Castellini, C., Berri, C., Le Bihan-Duval, E. \& Martino, G., 2008. Qualitative attributes and consumer perception of organic and free-range poultry meat. Wrld Poult. Sci. J. 64, 500-512.

Cook, M.E., Miller, C.C., Park, Y. \& Pariza, M., 1993. Immune modulation by altered nutrition metabolism: Nutritional control of immune-induced growth depression. Poult. Sci. 72, 1301-1305.

Crandall, P.G., Seideman, S., Ricke, S.C., O'Bryan, C.A., Fanatico, A.F. \& Rainey, R., 2009. Organic poultry: Consumer perceptions, opportunities and regulatory issues. J. Appl. Poult. Res. 18, 795-802.

Dransfield, E. \& Sosnicki, A., 1999. Relationship between muscle growth and poultry meat quality. Poult. Sci. 78, 743-746.

Evans, T., 2008. Poultry now a third of all meats. Poult. Int. 8, 29-31.

Fanatico, A.C., Cavitt, L.C., Pillai, P.B., Emmert, J.L. \& Owens, C.M., 2005. Evaluating of slow-growing broiler genotypes grown with and without outdoor access: Meat quality. Poult. Sci. 84, 1785-1790.

Fanatico, A.C., Pillai, P.B., Emmert, J.L. \& Owens, C.M., 2007. Meat quality of slow-and fast growing chicken genotypes fed low-nutrient or standart diets and raised indoors or with outdoor access. Poult. Sci. 86, 2245-2255.

Fletcher, D.L., 1999. Poultry Meat Color. In: Poultry Meat Quality. Eds Richardson, R.I. \& Mead, C., CAB Publishing, New York, NY. pp. 159-176.

Folch, J., Lees, M. \& Sloane-Stanley, G.H., 1957. A simple method for the isolation and purification of total lipids from animal tissues. J. Biol. Chem. 226, 497-509. 
Givens, D.I., Gibbs, R.A., Rymer, C. \& Brown, R.H., 2011. Effect of intensive vs. free range production on the fat and fatty acid composition of whole birds and edible portions of retail chickens in the UK. Food Chem. 127, 1549-1554.

Grashorn, M.A., 2005. Aspects of nutrition and management of meat quality. Proceedings of the XVII ${ }^{\text {th }}$ European Symposium on the Quality of Poultry Meat, 2005 May 23-26; Doorwerth.

Grashorn, M.A. \& Serini, C., 2006. Quality of chicken meat from conventional and organic production. Proceedings of the XII. European Poultry Conference, 2006 September 10-14; Verona.

Husak, R., Sebranek, J.G. \& Bregendahl, K.A., 2008. A survey of commercially avaliable broilers marketed as organic, free range and conventional broilers for cooked meat yields, meat composition and relative value. Poult. Sci. 87, 2367-2376.

Jahan, K., Paterson, A. \& Spickett, C.M., 2004. Fatty acid composition, antioxidant and lipid oxidation in chicken breast from different production regimes. Int. J. Food Sci. Technol. 39, 443-453.

Le Bihan-Duval, E., Millet, N. \& Remignon, H., 1999. Broiler meat quality: Effect of selection for increased carcass quality and estimates of genetic parameters. Poult. Sci. 78, 822-826.

Martino, G., Ponzielli, V. \& Grotta, L., 2008. Healthier fat content through organic production. Wrld Poult. 24, 33-34.

Nielsen, B.L., Thomsen, M.G., Sorensen, P. \& Youngi, J.F., 2003. Feed and strain effects on the use of outdoor areas by broilers. Br. Poult. Sci. 44, 161-169.

Owens, C., Fanatico, A., Pillai, P., Meullenet, J. \& Emmert, J., 2006. Evaluation of alternative genotypes and production systems for natural and organic poultry markets in the U.S. Proceedings of the XII. European Poultry Conference, 2006 September 10-14; Verona.

Quentin, M., Bouvarel, I., Berri, C., Le Bihan-Duval, E., Baeza, E., Jego, Y. \& Picard, M., 2003. Growth, carcass composition and meat quality response to dietary concentrations in fast, medium and slow growing commercial broilers. Anim. Res. 52, 65-77.

Ponte, P.I.P., Alves, S.P., Bessa, R.J.B., Ferreira, M.A., Gama, L.T., Bras, J.L.A., Fontes, C.M.G.A. \& Prates, J.A.M., 2008. Influence of pasture intake on the fatty acid composition, and cholesterol, tocopherols, and tocotrienols content in meat from free-range broilers. Poult. Sci. 87, 80-88.

SAS, 1995. SAS User's Guide, Statistics Edition. SAS Institute Inc. N.C. USA.

Sundrum, A., 2001. Organic livestock farming. A critical review. Livest. Prod. Sci. 67, 207-215.

Toyomizu, M., Sato, K., Taroda, H. \& Akiba, Y., 2001. Effect of dietary spirulina on meat colour in muscle of broiler chickens. Br. Poult. Sci. 42, 197-202.

Wattanachant, S., Benjakul, S. \& Ledwars, D.A., 2004. Composition, color, and texture of Thai indigenous and broiler chicken muscles. Poult. Sci. 83, 123-128. 